\title{
Project-Based English Language Instruction: A Study of Secondary School Learners in India
}

\author{
Syed Faiz Zaidi \\ Aligarh Muslim University, India
}

\begin{abstract}
The idea of Project-Based Learning (PBL) is based on a holistic instructional strategy, which is becoming more meaningful in today's society as teachers increasingly teach groups of young learners having different learning styles and ability levels. These learners primarily come from the northern part of India and have not been properly exposed to the learning of English because of varied linguistic, cultural, schooling and social backgrounds. The study aims at assessing the effectiveness of PBL in teaching young learners (14-16 years of age) Aligarh Muslim University, India. The methods employed in the study rely on data obtained with both qualitative and quantitative research instruments.
\end{abstract}

Keywords: Project-based language instructions, project-based learning

\section{INTRODUCTION}

Students' lack of adequate English language background primarily because of varied linguistic, cultural, schooling and social backgrounds as well as different ability levels has been identified as one of the critical problems in teaching and learning English at secondary level in North India. Most of the students hail from a linguistic and cultural background where English is not emphasized. Indeed, English must compete with their native Hindi or Urdu languages. These students are of non-elite background and previously had studied English through traditional forms of English language instruction which memorizes and crams texts. In an ideal situation, English language acquisition not only focuses on syntactic accuracy or competency in grammar usage, but also gives opportunities to use English in real life contexts. To deal with this challenge English language teachers North India 
need to employ an appropriate methodology for imparting English language learning that encourages students to use language with an emphasis on communicative purposes in real world settings. Project-based learning (PBL) seems to match this learning need.

The most important recent shift in education especially in English language learning has been the increased emphasis on standards, clear outcomes, and accountability. "Doing projects" is a long-standing tradition in education (Grant, 2002; Merkham, et al. 2003). The need for education to adapt to a changing world is the primary reason that PBL has become interdisciplinary. PBL is simply defined as "an instructional approach that contextualizes learning by presenting learners with problems to solve or products to develop" (Moss \& Van Duzer, 1998, p.1) PBL is not a new approach in education. It can be traced back to the mid - 1800s and was first created by David Snedden who taught science in American agriculture classes. It was introduced to ESL/EFL education during the seventies (Hedge, 1993).

\section{LITERATURE REVIEW}

So far, no such study about PBL and Access program has been conducted in India. However, the recent study of Sana Imtiaz, on the Access program in Pakistan (2012) has highlighted students' transformations into autonomous learners through PBL and developing positive self-images. She concluded that, while working on the projects the students learned not only language skills but also life skills, such as working in a team, self-regulation, selfmotivation and time management. ZakiaSarwar used a similar research framework to explore the impact of PBL in promoting learner autonomy among college students in Pakistan (2000). Sarwar (2001, p.135) pointed out in her research findings that "The transition from learner dependence to independence was not an easy process, especially in a system of education where spoon-feeding and rote-learning are common teaching learning strategies... Learners felt more in control and willing to work and perform and there was a great change in the student's confidence. The study revealed that the students' responses and enthusiasm for PBL helped them to achieve autonomy. The study also reported that lack of time, anxiety and group dynamics were the major problems encountered by the college students while doing project work.

Even though there is an extensive literature including research evidence, on the benefits and success of PBL research on how it could affect English language acquisition in the Indian education system is limited. Little empirical research has been done to present any challenges to PBL in second and foreign language learning; therefore an inquiry on the implementation and integration of PBL in Access classes would significantly enhance research knowledge and would prove to be useful for improving teaching 
and learning of English in Access Program in particular, and in India in general. The present study attempts to investigate the effect of PBL on the language performanceof the target learners. These learners were enrolled in a two-year intensive English language learning program.

\section{An Overview of the English Access Micro-scholarship Program}

The English Access Micro-scholarship Program provides a foundation of English language skills to non-elite, 14 - 18 year old students through afterschool classes and intensive learning activities. Since its inception, approximately 70,000 students in more than 85 countries have participated in the Access Program. This two year integrated program was introduced at Aligarh, India in 2007. The main objective of the course is to have students practice English language through the integration of skills and understanding by using authentic materials such as texts, newspaper and other print materials. The program aims at developing critical thinking among the students and making them autonomous learners through a variety of teaching methods, one such method is Project Based Learning.

\section{METHOD}

To achieve the aims of the study, both quantitative and qualitative research instruments were used to collect data from an EFL Access classroom. The quantitative instruments comprised a pre and post-test on LSWR skills. An observation schedule was also employed to examine the use of the English language by the students. The quantitative data were processed statistically and the descriptive results were based on the statistical differences of the pre-test and post-test. Additional information was obtained from qualitative instruments including students' project journals, work-in-progress discussions, and the field notes of the researcher. Semi-structured interviews enabled students to reconstruct the details of their learning experiences while working on the project. To investigate the English proficiency of different levels, the students were divided into three groups, high, medium and low, based on the raw scores collected from the results of the pre-tests on LSWR skills.

\section{An Interdisciplinary Project}

An Access class of twenty five students of fourteen females and 11 males during the second quarter of the two year integrated program in 2011-12 was the locus of this research As a course requirement one interdisciplinary project was planned to allow the students to apply both their knowledge of the content as well as their English language skills. The teacher asked the students to work in groups of four to five to execute community service projects on the themes: Care for the Elderly People and School Drop Outs respectively. 


\begin{tabular}{|c|c|c|}
\hline Phase 1 & $\begin{array}{l}\text { Students and } \\
\text { teacher agree on a } \\
\text { theme for the } \\
\text { Project. }\end{array}$ & $\begin{array}{l}\text { In order to determine the topic of the project and the } \\
\text { importance of community service projects, teacher queries } \\
\text { students on social evils of the society. Students reflect by } \\
\text { giving information and listing the social evils prevalent in } \\
\text { society. }\end{array}$ \\
\hline Phase 2 & $\begin{array}{l}\text { Students and } \\
\text { teacher determine } \\
\text { the final shape of } \\
\text { the project. }\end{array}$ & $\begin{array}{l}\text { Access teacher and the students decide which form their } \\
\text { project should take. They choose from the options of } \\
\text { writing a report, giving a power point presentation or a } \\
\text { poster presentation. }\end{array}$ \\
\hline Phase 3 & $\begin{array}{l}\text { Students and } \\
\text { teacher structure } \\
\text { the project. }\end{array}$ & $\begin{array}{l}\text { The students and the teacher decide the ways of getting } \\
\text { information about the topic for carrying out the project. The } \\
\text { students plan together using information from the internet, } \\
\text { newspapers, interviews and discussion. }\end{array}$ \\
\hline Phase 4 & $\begin{array}{l}\text { The teacher } \\
\text { designs the } \\
\text { activities }\end{array}$ & $\begin{array}{l}\text { In this phase, the teacher assesses language skills required } \\
\text { by the students for the task of gathering information. The } \\
\text { language activities planned focus mostly on reading } \\
\text { strategies, such as skimming, scanning and critical reading. }\end{array}$ \\
\hline Phase 5 & $\begin{array}{l}\text { Students gather } \\
\text { information }\end{array}$ & $\begin{array}{l}\text { Once the students are aware of the use of linguistic skills, } \\
\text { they gather information by bringing pictures, materials, } \\
\text { videos or by giving ideas on collecting the relevant } \\
\text { material. }\end{array}$ \\
\hline Phase 6 & $\begin{array}{l}\text { The teacher } \\
\text { prepares students } \\
\text { to process the } \\
\text { information } \\
\text { collected }\end{array}$ & $\begin{array}{l}\text { After having collected the information on their assigned } \\
\text { topic, students started working on compiling it, choosing } \\
\text { the most appropriate materials and summarizing it. }\end{array}$ \\
\hline Phase 7 & $\begin{array}{l}\text { Students compile } \\
\text { and analyze the } \\
\text { information }\end{array}$ & $\begin{array}{l}\text { Once the students processed all the information, they had to } \\
\text { compile and organize it appropriately for the presentation. }\end{array}$ \\
\hline Phase 8 & $\begin{array}{l}\text { The teacher } \\
\text { prepares the } \\
\text { students for the } \\
\text { final presentation }\end{array}$ & $\begin{array}{l}\text { The teacher prepares students for the final presentation of } \\
\text { their project. For this purpose, presentation skills are } \\
\text { improvised through different classroom activities with the } \\
\text { help of rubrics. Student with the help of the teacher create } \\
\text { rubrics for presentation from the website: } \\
\text { http://rubistar.4teachers.org }\end{array}$ \\
\hline Phase 9 & $\begin{array}{l}\text { Students present } \\
\text { the final out-come } \\
\text { of their project }\end{array}$ & $\begin{array}{l}\text { In this phase, the students plan and give the final } \\
\text { presentation of their projects in the form of Power point } \\
\text { presentations. }\end{array}$ \\
\hline Phase 10 & $\begin{array}{l}\text { Students evaluate } \\
\text { each other's } \\
\text { projects. }\end{array}$ & $\begin{array}{l}\text { In the last phase, the students were asked to provide } \\
\text { feedback on the presentations of each group. }\end{array}$ \\
\hline
\end{tabular}


Zaidi, Project-Based English Language Instruction|35

\section{Steps of Project Development}

\section{Assessment of PBL}

Assessment of PBL in English language class can be different and even challenging compared to assessment of a traditional English language class. Students in PBL are assessed by various means, such as using research instruments comprising of tests, self-assessment and peer assessment. Formative assessment plays a critical role in PBL as it can be built into this integrated learning approach. Moreover, self-assessment and peer assessment can be integrated into formative assessment. Self-assessment allows learners to evaluate their own work and progress while peer assessment gives the opportunity for group members to evaluate their group work, progress and the need to improve the work.

Rubrics can also be used as an assessment tool, but they should be carefully designed by the teacher as they need to meet the class instructional goals and the objectives of the project. Rubrics should contain three features: (a) a set of aspects of product or performance (b) a scale with numerical scores describing each level of performance and (c) criteria with specific indicators for evaluating a product or performance's quality (Markham et al., 2003). Rubrics can also help students to evaluate and prepare their final presentations with respect to preparedness, time limit, speech clarity, vocabulary, content and body language. For the project students and teacher designed rubrics through the website: http://rubistar.4teachers.org

\section{LSWR Test and Observation schedule (Quantitative)}

To evaluate student's proficiency in LSWR skills at the beginning of the project, the students took pre-tests as part of a quantitative instrument developed by the researcher. The test included questions related to listening and reading comprehension, and written expression. Two hours were allotted to complete the test. In addition, students were asked to take a speaking test sometime during the second or third week. Based on the raw scores of the pre-test the teacher determined the level of the students as low, medium and high and formed a basis for evaluating three different leveled students' acquisition of LSWR skills towards the next phases of the project. All 25 participants also undertook the LSWR post-test during the last weeks using the same test format as the pre-test with the same amount of time allocated. 
Comparison of the pre and post-test of LSWR for Low, Medium, and High level (Quantitative Instruments):

\begin{tabular}{|c|c|c|c|c|c|c|c|c|}
\hline & \multicolumn{2}{|c|}{ Listening } & \multicolumn{2}{|c|}{ Speaking } & \multicolumn{2}{|c|}{ Reading } & \multicolumn{2}{|c|}{ Writing } \\
\hline \multirow{3}{*}{$\begin{array}{l}\text { High } \\
5 \text { Students }\end{array}$} & Pre & Post & Pre & Post & Pre & Post & Pre & Post \\
\hline & $40 / 50$ & $41 / 50$ & $38 / 50$ & $48 / 50$ & $39 / 50$ & $41 / 50$ & $40 / 50$ & $47 / 50$ \\
\hline & \multicolumn{2}{|c|}{$\begin{array}{l}\text { S.D: } \\
\text { No significant } \\
\text { change }\end{array}$} & \multicolumn{2}{|c|}{ S.D: +10} & \multicolumn{2}{|c|}{$\begin{array}{l}\text { S.D: } \\
\text { No significant } \\
\text { change }\end{array}$} & \multicolumn{2}{|c|}{ S.D: +07} \\
\hline \multirow{3}{*}{$\begin{array}{l}\text { Medium } \\
9 \text { students }\end{array}$} & Pre & Post & Pre & Post & Pre & Post & Pre & Post \\
\hline & $62 / 90$ & $74 / 90$ & $58 / 90$ & $71 / 90$ & $63 / 90$ & $77 / 90$ & $66 / 90$ & $77 / 90$ \\
\hline & \multicolumn{2}{|c|}{ S.D: +12} & \multicolumn{2}{|c|}{ S.D: +13} & \multicolumn{2}{|c|}{ S.D: +14} & \multicolumn{2}{|c|}{ S.D: +11} \\
\hline \multirow{3}{*}{$\begin{array}{l}\text { Low } \\
11 \text { Students }\end{array}$} & Pre & Post & Pre & Post & Pre & Post & Pre & Post \\
\hline & $68 / 110$ & $84 / 110$ & $60 / 110$ & $77 / 110$ & $65 / 110$ & $85 / 110$ & $62 / 110$ & $77 / 110$ \\
\hline & \multicolumn{2}{|c|}{ S.D: +16} & \multicolumn{2}{|c|}{ S.D: +17} & \multicolumn{2}{|c|}{ S.D: +20} & \multicolumn{2}{|c|}{ S.D: +15} \\
\hline
\end{tabular}

In order to investigate the effect of PBL on the Language performance of the target learners and to understand the student's gains, the quantitative data derived from the comparison of pre-test and post-test scores were analyzed. The data, available only in numerical form allow the researcher to see simple numerical figures for start and end points with the statistical difference.

\section{Semi-structured interview: Responses to the open-ended questions}

\begin{tabular}{|c|c|c|c|c|}
\hline & Listening & Speaking & Reading & Writing \\
\hline High & $\begin{array}{l}\text { I enjoy listening } \\
\text { to my peers and } \\
\text { giving them } \\
\text { feedback. }\end{array}$ & $\begin{array}{l}\text { I feel confident } \\
\text { and energetic } \\
\text { to have } \\
\text { conversation } \\
\text { in English using } \\
\text { various } \\
\text { expression }\end{array}$ & $\begin{array}{l}\text { It was yet another } \\
\text { opportunity to } \\
\text { read the relevant } \\
\text { material on the } \\
\text { topic. }\end{array}$ & $\begin{array}{l}\text { Project Journals } \\
\text { and presentations } \\
\text { helped me to take } \\
\text { notes and improve } \\
\text { my writing skills }\end{array}$ \\
\hline Medium & $\begin{array}{l}\text { I can listen to } \\
\text { select content that } \\
\text { I am looking for } \\
\text { and able to } \\
\text { respond to }\end{array}$ & $\begin{array}{l}\text { I have developed } \\
\text { speaking skills. I } \\
\text { can respond to } \\
\text { the questions } \\
\text { asked during my }\end{array}$ & $\begin{array}{l}\text { I was not able to } \\
\text { comprehend } \\
\text { the text. } \\
\text { With the help of } \\
\text { the teacher } \\
\text { I gradually }\end{array}$ & $\begin{array}{l}\text { Reading } \\
\text { comprehension } \\
\text { in turn helped me } \\
\text { to improve my } \\
\text { writing skills }\end{array}$ \\
\hline
\end{tabular}


Zaidi, Project-Based English Language Instruction|37

\begin{tabular}{|c|c|c|c|c|}
\hline & questions & presentation & $\begin{array}{l}\text { developed and } \\
\text { used } \\
\text { the strategies of } \\
\text { reading }\end{array}$ & \\
\hline Low & $\begin{array}{l}\text { I have improved } \\
\text { listening } \\
\text { comprehension } \\
\text { during } \\
\text { discussions and } \\
\text { interviewing } \\
\text { people. }\end{array}$ & $\begin{array}{l}\text { I have improved } \\
\text { my } \\
\text { pronunciation } \\
\text { and feel } \\
\text { confident while } \\
\text { speaking }\end{array}$ & $\begin{array}{l}\text { It took a long time } \\
\text { to find the main } \\
\text { and supporting } \\
\text { idea. While } \\
\text { reading I went } \\
\text { through } \\
\text { information many } \\
\text { times to } \\
\text { comprehend. At } \\
\text { least I tried instead } \\
\text { of giving up }\end{array}$ & $\begin{array}{l}\text { Teacher helped me } \\
\text { to review my } \\
\text { Journals and } \\
\text { identify the errors } \\
\text { in the grammatical } \\
\text { structure of my } \\
\text { written work. }\end{array}$ \\
\hline
\end{tabular}

\section{Acquisition of English language Skills}

\section{Listening and speaking}

There were three developmental stages in the acquisition of listening and speaking skills during the project: a) Initial b) Medial and c) Final. Initial stage of listening and speaking skills came soon after the investigation of the topic of the project. Students shared their opinion in the class during workin-progress discussion. The aim of the discussion was to give students opportunity to present their ideas and at the same time to engage learning. In addition, the researcher could evaluate their English language skills. During their first discussion (Phase-1), a number of the students demonstrated low level performance in listening and speaking skills; According to the teacher's observations, (Field note. June 27): It took quite some times for the students to shrug off the hesitation and tongue tiedness. It was not their lack of content but possibly the lack of confidence in speaking English. Moreover, it seemed to be the case of parroting and spoon-feeding orientation they carried from their feeder institutions.

During the medial stage, students exhibited some improvement. Since, the students felt that they had difficulties with their speaking and listening skills initially, they worked with the strategies based on feedback from their peers and teacher. Each member agreed to present their information in front of their team and to prepare at least one question to ask their peers. Students interviewed people on the topic of the project in order to collect information and thus, practice listening and speaking skills. Twenty students indicated that they improved their listening and speaking skills by interviewing. They spoke clearly, understood things, and felt confident to express themselves. It was a surprise to learn that three out of five groups developed a selection of 
short dialogues and key phrases to enhance their speaking skills for use within their groups and during their interaction with the teacher. Two out of five groups practiced their presentations using rubrics within their own group and practiced listening and responding while giving a presentation. Since the final stage or presentation they showed confidence in speaking and listening. The observer noted that there was a gradual transformation and change in spoken form. Students have worked for the project for weeks and seemed to have gained confidence and learned the use of language for communicating in real context.

\section{Reading Skills}

In the process of completing their projects, students had the opportunity to experience a wide and varying range of information through reading either from newspapers, magazines or the information available on internet. In order to gain a deeper knowledge of the topic, they read extensively and collected information. Towards the end of the study, it was found that the students developed their reading skills in the areas of summarizing information and. comprehending the main idea through skimming and scanning. Teachers' observations and notes show the students' development of reading skills and an ability to summarize. They understood well what they had read as their summary and stated the principal idea and supporting details in their own words. It is clear that PBL provided the students with the opportunity to experience both authentic reading materials and authentic purposes for reading and summarizing. Because the students were involved with their own learning process, they could choose what to read based on their interests. So, they were motivated to read for their own benefit. They not only gained valuable comprehension experience but also improved their summarizing skills and vocabulary.

\section{Writing Skills}

A comparison the quantitative data collected from the results of the pre-test and post-test of LSWR reveals a significant improvement in the writing skills of students at all levels. It was evident through the response of the students to open-ended question as an interview format towards the end of the study. Nineteen out of twenty five students claimed that their writing ability had developed through reading comprehension because their projects were related to real-life topics and required understanding how language was used outside the classroom. Students read several information sources to increase their use of grammar structure, vocabulary and their writing. As their reading improved, students began to comprehend how written language should be organized and used to achieve specific goals. When asked what they had read in English for their information, students stated that nearly $95 \%$ of their reading materials were authentic texts (G9-Table-2) such as newspapers, articles, magazines, brochures and websites. 
The interview data also revealed that the students believed that their language skills were enhanced. Table 2 shows some of students' opinions about skills enhancement.

\section{Interview Data Example}

G1: "We thought about what sentences or speech we were going to write in the project."

G4: "We read some information before putting it on record....We thought we applied the speaking skill. Some words we have never spoken before such as in addition."

G3: "[We learned] English language and technical terms relating to Internet."

G3: "I haven't thought that many skills can absolutely apply for it. It the past, my English was not really good. It's now better, and it's really fun.

G5: Interviewing people was an amazing experience. We worked to frame questions and practiced to jot the responses.

G2: Reading authentic texts was a novel experience and helped us to improve writing

G5: "[We used] reading and writing of English texts"

Most of them thought that the project helped them practice their LSWR skills. At the preparation stage of their presentation, the students believed that their critical thinking (G1), reading skill (G4) as well as vocabulary were enhanced when they searched for information from different sources because they had to read and compare this information before selecting what was appropriate for their project. Their writing was also enhanced when they wrote scripts for their power point presentation or posters. For example, students of Groups 2 and 5 used both reading and writing skills to complete their work. Students enjoyed interviewing people (G5)

\section{RESULTS}

This study was conducted by employing mixed methods research with both quantitative and qualitative instruments to determine and gauge Access students' English language development through PBL. The data collected from the research instruments were organized into categories. It was then summarized, interpreted and compared, thereby helping the researcher to determine the effect of PBL on English Language acquisition. Discussion and responses to the interview format or open-ended questionnaires were also shown and reported. The quantitative data revealed that there was a statistically significant effect on the development of low and medium achievers' English language skills. The high achieving students showed progress in speaking and writing but their listening and reading skills showed no significant improvement at the end of the study. However, through PBL the high achieving students' enhanced their skills sets such as 
teamwork, critical thinking, and presentation skills. This was evident from the reflections of the students and qualitative data analysis.

The qualitative data revealed that the group of low achievers improved their writing and reading skills through cooperative and collaborative learning and peer feedback. The greatest beneficiaries were the medium level students who improved their overall English language skills, grammar and vocabulary and learned ways of working collaboratively. It should be noted that comprehensively all levels of students received great benefits from collaborative learning as they had formed teams based on their close relationships with each other and their common interest in practicing English language skills.

PBL had an overall positive effect on the acquisition of English language skills. Table3 shows this comprehensive and significant improvement based on the data derived from the research instruments.

\section{Overall Improvement}

\begin{tabular}{|c|c|c|c|c|}
\hline \multirow{2}{*}{ Skills } & \multicolumn{4}{|c|}{ Significant enhancement of the skills } \\
\hline & Low & Medium & High & Whole Class \\
\hline Listening & $\checkmark$ & $\checkmark$ & $x$ & $\checkmark$ \\
\hline Speaking & $\checkmark$ & $\checkmark$ & $\checkmark$ & $\checkmark$ \\
\hline Reading & $\checkmark$ & $\checkmark$ & $x$ & $\checkmark$ \\
\hline Writing & $\checkmark$ & $\checkmark$ & $\checkmark$ & $\checkmark$ \\
\hline Grammar & $x$ & $\checkmark$ & $\checkmark$ & $\checkmark$ \\
\hline Vocabulary & $\checkmark$ & $\checkmark$ & $x$ & $\checkmark$ \\
\hline
\end{tabular}

The teacher's notes and observations reveal that twenty-three out of twentyfive students wanted to learn in a real environment with hands-on activities and teacher's guidance. Fifteen out of twenty-five students wanted to choose their own routes of learning as they thought that it would give them autonomy. Fourteen out of twenty-five students believed that communicating with friends and teachers could trigger motivation and enthusiasm. In addition, twelve out of twenty-five students showed their interest in experiencing learning activities outside the classroom, especially interviewing people. It is important to note that the low and medium achievers within the groups were encouraged by their peers to use English 
and to interact with the teacher and people outside classroom; this was a crucial factor in the development of their English proficiency.

\section{CONCLUSION}

The study concluded that PBL could be an effective means of teaching English as a foreign language and that it could be successfully employed with students who previously had only been exposed and subjected to a background of traditional forms of teaching and learning. PBL had an overall positive effect on the acquisition of English language skills. The study reveals that there was significant effect on the development of low and medium achievers' English language skills. In particular, the low achievers improved their writing and reading skills through cooperative and collaborative learning and peer feedback. The greatest beneficiaries were the medium level students who improved their overall English language skills, grammar and vocabulary and also learned ways of working collaboratively. Through PBL, the high achieving students' enhanced skills such as teamwork, critical thinking and presentation evident from the reflections of students and qualitative data analysis. The high achieving students showed progress in speaking and writing but their listening and reading skills showed no significant improvement at the end of the study.

The study also confirmed that the characteristics of PBL contributed to further development of English language proficiency, autonomy and student teamwork. Exposure to authentic English language skills helped students to analyze and synthesize information while working on their project. Scaffolding by the teacher during the project was essential and extensive for the development of English language skills and confidence of the students. During the project, the teacher assisted students to hone their English skills. The study also revealed some important aspects of assessment in PBL. Self and peer assessment helped students to determine and evaluate the progress of their work. Students used rubrics to assess and prepare their presentations .The activities devised by the teacher to implement PBL in class enhanced students motivation and helped them to learn how to work collaboratively and cooperatively. However, there were mixed reactions to and results of the implementation plan.

This study implemented PBL in the form of the interdisciplinary-based project in the Access class helping students to link their English language skills with their content knowledge. One of the most interesting findings regarding the implementation of the project-based activity was that the students found a balanced use of their English language skills, awareness of the social issues and information technology infused in their project. This finding corroborated findings from a large number of studies in this field, which show that PBL activities allow students to integrate language skills 


\section{$42 \mid$ ELT Worldwide Vol. 1 No. 1}

and content knowledge to complete the projects. The present study was able to demonstrate a good implementation plan. However, the interviews with the students, and the teacher's notes showed that the students needed better preparation for their project presentations. A possible explanation for this might be that even though the students practiced English skills in class, they were not familiar with doing an English presentation in front of the class. Thus, an adjustment of the implementation plan and an addition of instructional activities regarding English presentation practice are needed for future implementation. With respect to enhancement of students' language skills, the findings of the study are consistent with those of Srikrai (2008) and Simpson (2011) who found that students' language skills were enhanced through project-based activities.

As the project progressed, the students became more confident in communicating in English and acquired a greater depth of understanding of social issues and language use. In later sessions, the quieter students were able to ask questions and were more willing to express their opinions. They reported that the feedback from the teacher during and after discussions helped them to develop their linguistic accuracy. The evidence from the study supports the contention that teacher - student interaction is central to the success of both linguistic and communicative competence (Savignon. 1983). Almost all students reported that it was their first experience of working on a community service project. Moreover, they were involved in a project that did not affect their grades. Almost all students enjoyed interviewing people and this helped them to improve their listening and speaking skills. The study leads us two important pedagogical implications. First, it is reasonable and productive to include an inter-disciplinary project in an English class, especially in EFL contexts, where opportunities to use English are limited. Second, since PBL can encourage learners to use English language skills, to enhance their social and language skills, assessing the acquisition of these skills is reasonable.

\section{Limitations of the Study}

There are some limitations to this study as it was an exploratory investigation to determine the effect of PBL on the acquisition of English language skills. The findings cannot be generalized to overall PBL use in EFL/ESL courses in India because the study was conducted with only one group of students in India. However, the findings are likely to be relevant to those in similar contexts. Further research is needed with students in related educational contexts as the methodological limitation relates to student reflections. Finally, the small group of students in this study is also a limitation as the average class size of students in India is around 50-60. It would be more challenging to implement PBL successfully in an average class with the same pedagogical practices of this study. Therefore, some 
practices including the level of support, the feedback frequency and the time allocated to discussion, should be modified to suit the larger class population.

\section{Directions for Future Research}

The implications and limitations of this study lead to a number of possible directions for future research. Even though this study has provided results and analysis of the acquisition of LSWR skills, and an implementation plan of PBL in EFL/ESL classroom,it remains limited and further study could advance the use of PBL within the Indian education system as well as similar educational contexts. Further research is needed to examine how teachers can manage PBL more effectively in the classrooms in different cultural teaching and learning contexts.

The present study focused on the findings of only one group of students. It would be worthwhile to examine students from other groups, both of similar and different educational settings, to validate the findings of this study. Furthermore, due to the limitation of the sample size, it would be valuable for further research to be conducted to address the results of using PBL with large classes. Future research may investigate the attitudes of teachers towards the use of PBL. It would be interesting to see whether Indian teachers in similar as well as different educational settings are prepared to implement PBL in their classes. It would also be interesting to study whether the students feel motivated and enthusiastic about projects other than community service ones.

\section{REFERENCES}

Beckett, G. H.\& Slater, T. (2005). Theprojectframework: a tool for language, content and skills integration. ELT Journal, 59(2), 108-116.

Fried- Booth. D.L. (2002). Project work. Oxford: Oxford University press.

Grant, M.M. (2002).Getting a grip on Project-based Learning: Theory, cases and recommendations. Meridian Journal, 5(1), 1-17

Hedge, T. (1993). Key concepts in ELT. ELT Journal, 47(3), 275-277

Imtiaz, S. (2012). I almost learnt to learn: Promoting learner's autonomy throughProject-based Learning in access classrooms.

Jennifer, R. (2002). Project Based instruction: Creating excitement for learning.North West Regional Educational Laboratory

Markham, T. (2003).Project Based Learning handbook. Canada: Buck Institute for Education 
44 | ELT Worldwide Vol. 1 No. 1

Moss, D. \& Van Duzer, C. (1998).Project based learning for adult English language learners. ERIC Reproduction Services. No. ED 427556

Newell, R.J.(2003).Passion for learning: How project-based Learning meets the needs of $21^{\text {st }}$ century students. Lanham, MD: Scarecrow Press

Sarwar, Z. (2000). Research on Project-based learning to facilitate learner autonomy. Retrieved from www.hayo.nl/lapi/zakia_sarwar.doc

Savignon. S.J. (1983) Communicative competence: Theory and classroom practice. Reading, Mass: Addison Wesley

Srikrai, P. (2008). Project-based learning in an EFL classroom. Journal of Humanities and Social Sciences, Khon Kean University, 25, 85 - 111.

Stoller, F. (1997).Project work: A means to promote language content. Forum, 35(4), 2-20

\section{Appendix}

LSWR Quantitative Test:

http://esl.about.com/library/listening/bllis_interview.htm

Listening Test- An Interview with a Famous Dancer.

http://esl.about.com/od/esleflteachingtechnique/a/lmh_speaking.htm Speaking Test- Student Interviews.

http://esl.about.com/od/readingintermediate/a/r_social.htm

Reading Test- Social Networking Sites.

http://esl.about.com/od/writingintermediate/a/describing_cities.htm

Writing Test- Writing about Cities - Portland Oregon. 